\title{
Estrogen receptor $\beta 1$ exerts antitumoral effects on SK-OV-3 ovarian cancer cells
}

\author{
Oliver Treeck*, Georg Pfeiler*, Diana Mitter, Claus Lattrich, Gerhard Piendl and Olaf Ortmann \\ Department of Obstetrics and Gynecology, Klinik für Frauenheilkunde und Geburtshilfe, University of Regensburg, Landshuter Strasse 65, 93053 Regensburg, \\ Germany \\ (Requests for offprints should be addressed to O Treeck; Email: otreeck@caritasstjosef.de) \\ *(O Treeck and G Pfeiler contributed equally to this study)
}

\begin{abstract}
Estrogen receptor (ER) $\beta 1$ and its splice variants are expressed both in ovary and ovarian cancer. We studied the role of ER $\beta 1$ and two of its splice variants in regulation of gene expression, cellular proliferation, apoptosis, and migration of an ovarian cancer cell line. In this study, we transfected SK-OV-3 ovarian cancer cells with vectors coding for ER $\beta 1$ or its splice variants $E R \beta-\delta 125$ and $E R \beta-\delta 1256$, and tested their response to estrogen and tamoxifen in comparison with the untransfected cells. Heterologous expression of ER $\beta 1$, but not of the exon-deleted ER $\beta$ variants resulted in notably slower cell growth of SK-OV-3 ovarian cancer cells, an effect

accompanied by more than tenfold increase of cyclindependent kinase inhibitor p21(WAF1) transcript levels and a significant reduction of cyclin A2 mRNA levels. SK-OV-3 cells stably overexpressing ER $\beta 1$ ligand independently also exhibited an increased apoptosis rate and a significantly decreased motility, an effect accompanied by upregulation of fibulin 1c. Our data demonstrate that $\operatorname{ER} \beta 1$, but not the exon-deleted isoforms tested exerts multiple antitumoral effects on SK-OV-3 ovarian cancer cells even in the absence of estradiol or functional ER $\alpha$.

Journal of Endocrinology (2007) 193, 421-433
\end{abstract}

\section{Introduction}

Although $40-60 \%$ of ovarian cancers express estrogen receptor (ER) $\alpha$ (Greenlee et al. 2000, Havrilesky et al. 2001), only a minor proportion of patients (ranging from 7 to $18 \%$ respond clinically to treatment with selective ER modulator tamoxifen (Hatch et al. 1991, Scambia et al. 1995). However, the role of estrogens has been recently highlighted by the results of three large prospective studies showing that estradiol uptake in postmenopausal stage increased the risk of ovarian cancer incidence and mortality in women who used long-term estrogen replacement therapy (Rodriguez et al. 2001, Lacey et al. 2002, Anderson et al. 2003). Estrogen effects are mediated by two ER types, named ER $\alpha$ and ER $\beta$ (Gustafsson 1999, Pettersson \& Gustafsson 2001, Osborne \& Schiff 2005). Although particularly the molecular mechanisms of ER $\beta$ function in ovary and ovarian cancer are still poorly elucidated, it is becoming increasingly clear that both receptor types are responsible for different biological functions, as indicated by their specific expression patterns and different effects of their gene knockout (Merchenthaler \& Shugrue 1999, Couse et al. 2000). Besides their different physiological functions, recent studies have suggested that $\mathrm{ER} \beta$, in contrast to $\mathrm{ER} \alpha$, might act as a tumor suppressor in breast or prostate cancer cells (Lazennec et al. 2001, Cheng et al. 2004), whereas other studies did not come to such conclusions (Burns et al. 2003). Given that $\operatorname{ER} \beta$ is able to counteract $\mathrm{ER} \alpha$ signaling in some settings, loss of $\operatorname{ER} \beta$ is thought to enhance ER $\alpha$-mediated proliferation of hormone-dependent cancer cells (Lindberg et al. 2003). Furthermore, recent studies suggested that ER $\beta$ signaling might affect cellular apoptosis (Cheng et al. 2004). An interesting feature of both ERs is the variety of their mRNA isoforms resulting from differential splicing (Price et al. 2000, 2001, Speirs et al. 2000, Poola et al. 2002a,b, Herynk \& Fuqua 2004). The so far identified ER $\beta$ splice variants are characterized by alternative $3^{\prime}$-exons $(\operatorname{ER} \beta 2, \operatorname{ER} \beta 3, \operatorname{ER} \beta 4$, ER $\beta 5$ ) or by deletion of single or multiple exons (e.g., $\operatorname{ER} \beta \Delta 2, \operatorname{ER} \beta \Delta 5 / 6)$. Some of these mRNA isoforms were demonstrated to code for ER $\beta$ proteins, which are characterized by impaired estrogen or DNA binding or altered cofactor interaction (Sierens et al. 2004, Zhao et al. 2005). The emerging picture of multiple ER $\beta$ mRNA isoforms, and thus also the multitude of differentially built proteins, strongly suggests their synthesis to be considered as another level of complexity of estrogen signaling.

A loss of ER $\beta$ expression or a decrease in $\operatorname{ER} \beta / \mathrm{ER} \alpha$ ratio in epithelial ovarian cancer as compared with normal tissues has been reported consistently by several groups (Pujol et al. 1998, Rutherford et al. 2000). However, the role of $\operatorname{ER} \beta$ and particularly its splice variants in ovarian carcinogenesis is not fully understood and the suggested role of ER $\beta$ as a tumor 
suppressor raised from observations on breast and prostate cancer cells (Merchenthaler \& Shugrue 1999, Lazennec et al. 2001) has to be tested with regard to ovarian cancer. In this study, we engineered SK-OV-3 ovarian cancer cells heterologously expressing ER $\beta 1$ or the exon-skipped ER $\beta$ splice variants $E R \beta-\delta 125$ and $E R \beta-\delta 1256$ recently identified by our group (Treeck et al. 2007). The predicted proteins coded by these novel ER $\beta$ isoforms lack the activation function 1 (AF-1) domain and have large deletions both in the ligandbinding domain (LBD) and the DNA-binding domain (DBD), and thus are expected to exhibit a drastically changed function profile in comparison with ER $\beta 1$. In this study, we examined to what extent expression of ER $\beta 1$ and two of its splice variants are able to modulate cellular proliferation, apoptosis, motility, and gene expression of ER $\alpha$-negative, estrogen unresponsive SK-OV-3 ovarian cancer cells.

\section{Materials and Methods}

\section{Materials}

Phenol red-free Dulbecco's Modified Eaglo's Medium (DMEM) culture medium was obtained from Invitrogen; Fetal Calf Serum (FCS) was purchased from PAA Laboratories $\mathrm{GmbH}$ (Pasching, Austria). 17- $\beta$ Estradiol (E2), 4-OH tamoxifen (4-OH TAM), ICI 182780 , staurosporine, and serum replacement 2 (SR2) were obtained from Sigma, SK-OV-3 and OVCAR-3 ovarian cancer cells were obtained from American Type Culture Collection (Manassas, VA, USA). M-MLV-P reverse transcriptase, Cell Titer Blue kit, Caspase-Glo 3/7 kit and ImProm-II Reverse Transkriptase were purchased from Promega. RNeasy Mini Kit, RNaseFree DNase Set, and Quantitect SYBR Green PCR Kit were obtained from Qiagen. PCR primers were synthesized at Metabion (Planegg-Martinsried, Germany). Transfectin reagent was obtained from Bio-Rad. Platinum Pfx Polymerase and OptiMEM medium were purchased from Invitrogen. Annexin V-FLUOS Staining Kit was obtained from Roche. Rapid-Scan gene expression panel was obtained from Origene (Rockville, MD, USA). siRNAs were obtained from Ambion (Austin, TX, USA).

\section{Plasmids}

Vector pTARGET (Promega) allows cloning in Escherichia coli and additionally carries the human cytomegalovirus immediateearly enhancer/promoter region to promote constitutive expression of cloned DNA inserts in mammalian cells. This vector also contains the neomycin phosphotransferase gene, a selectable marker for mammalian cells. pTARGET derivatives containing ORFs of ER $\beta 1, E R \beta-\delta 125$, or ER $\beta$ ? $\delta 1256$ were used for heterologous expression in SK-OV-3 cells. Vector pEGFP-N2 (Clontech) codes for the green fluorescent protein (GFP) for visualization of transfection efficacy using a fluorescence microscope. Vector pTAL-SEAP (Clontech) constitutively codes for the secreted alkaline phosphatase (SEAP) protein and served as positive control for the SEAP assay and the pTAL-estrogen response element (ERE)-SEAP is a reporter gene vector containing EREs in the promotor of the $S E A P$ gene. Both vectors were used for the reporter gene assays performed in this study. Vector pSV- $\beta$-GAL (Promega) constitutively codes for the $\beta$-galactosidase enzyme and was used as internal control for transfection efficacy in the reporter gene assays.

\section{Cell culture, transfections, and siRNA}

SK-OV-3 cells were maintained in phenol red-free DMEM/F12 medium supplemented with 10\% FCS. Cells were cultured with $5 \% \mathrm{CO}_{2}$ at $37^{\circ} \mathrm{C}$ in a humidified incubator. For transfection, $4 \times 10^{5} \mathrm{SK}-\mathrm{OV}-3$ cells per well of a 6-well dish were seeded in DMEM/F12 10\% FCS. The next day, $2 \mathrm{ml}$ fresh culture medium was added to the cells and the transfection solution was prepared by mixing $5 \mu \mathrm{l}$ Transfectin reagent (Bio-Rad) and $1 \mu \mathrm{g}$ plasmid DNA or $30 \mathrm{nM}$ siRNA in OptiMEM reduced serum medium (Invitrogen) and added to the cultured cells. For generation of stable clones, G418 selection $(300 \mu \mathrm{g} / \mathrm{ml})$ was started $48 \mathrm{~h}$ after transfection. For analysis of mRNA levels in siRNA-treated cells or for subsequent proliferation or apoptosis assays of siRNA-treated cells, transfected cells were harvested $24-48 \mathrm{~h}$ later. The siRNA sequence for knockdown of ER $\beta 1$ was $5^{\prime}$-CCUUACCUGUAAACAGAGAtt- $3^{\prime}$, the sequence of the scrambled negative-control siRNA was $5^{\prime}$-CCAGAUUCAGACCAAAUGUtt-3' (Ambion).

\section{RT and PCR}

Total RNA was isolated by means of the RNeasy kit (Qiagen) according to the manufacturer's instructions. From $1 \mu \mathrm{g}$ total RNA, cDNA was synthesized using $100 \mathrm{U}$ M-MLV-P reverse transcriptase (Promega), 2.5 mM dNTP mixture, and $50 \mathrm{pM}$ random primers (Invitrogen). For detection of $E R \beta$ splice variants by standard RT-PCR, $2 \mu \mathrm{l}$ cDNA was amplified in a reaction mix of $1 \mathrm{U}$ platinum polymerase (Invitrogen), $20 \mathrm{pmol}$ of each primer, $1 \times$ PCR-buffer, $1.5 \mathrm{mM} \mathrm{MgCl}_{2}$, and $2.5 \mathrm{mM}$ of each dNTP. The cDNA was amplified in 35 cycles $\left(1\right.$ cycle $=1 \mathrm{~min}$ at $94^{\circ} \mathrm{C}$ melting, $2 \mathrm{~min}$ at $56^{\circ} \mathrm{C}$ annealing, $3 \mathrm{~min}$ at $72{ }^{\circ} \mathrm{C}$ extension). All PCR primers were designed intron-spanning, sequences are indicated in Table 1 , position of $E R \beta$ primers is illustrated in Fig. 1.

For real-time PCR detection of ER $\beta$ isoforms or estrogen target genes, $2 \mu \mathrm{l}$ cDNA were amplified using the Quantitect SYBR Green PCR Kit (Qiagen) and the LightCyler PCR device (Roche Diagnostics). The PCR program was $95^{\circ} \mathrm{C}$ for $15 \mathrm{~min}$, followed by 35 PCR cycles $\left(95^{\circ} \mathrm{C}\right.$ for $10 \mathrm{~s}$, $56{ }^{\circ} \mathrm{C}$ for $30 \mathrm{~s}, 72{ }^{\circ} \mathrm{C}$ for $30 \mathrm{~s}$ ) and a final extension for $5 \mathrm{~min}$ at $72{ }^{\circ} \mathrm{C}$, followed by a standard melting curve analysis. In all RT-PCR experiments, a $190 \mathrm{bp} \beta$-actin fragment was amplified as reference gene using intron-spanning primers actin-2573 and actin-2876. After performing dilution 
Table 1 Primer sequences used for RT-PCR amplification

\section{Oligonucleo-} tides

\section{Target}

$\begin{array}{ll}\text { ER } \beta-\delta 125 & \delta 12 \\ & \delta 5 \\ \text { ER } \beta-\delta 1256 & \delta 12 \\ & \delta 56 \\ \beta \text {-Actin } & \text { Actin-2573 } \\ & \text { Actin-2876 } \\ \text { neo }^{r} & \text { pTAR1 } \\ & \text { pTAR2 } \\ \text { Fibulin-1c } & \text { Fib1 } \\ & \text { Fib2 } \\ \text { Cyclin A2 } & \text { CYCA-1 } \\ & \text { CYCA-2 } \\ \text { p21(WAF1) } & \text { WAF1 } \\ & \text { WAF2 }\end{array}$

Sequences $5^{\prime}-3^{\prime}$

GGTGTGTTTATCTGCAAGGACA CTCATCCCGGGAATCTTCTT GGTGTGTTTATCTGCAAGGACA CCAGAGGGTACATACCGGGAA CTGTGGCATCCACGAAACTA CGCTCAGGAGGAGCAATG ATGACTGGGCACAACAGACA CTCGTCCTGCAGTTCATTCA CGAGTGCCCTGAGAACTACC GATGTTGGTGGGGAAAGAGA CTGCTGCTATGCTGTTAGCC TGTTGGAGCAGCTAAGTCAAAA GCATGACAGATTTCTACCACTCC AAGATGTAGAGCGGGCCTTT experiments with sample cDNA over a 100-fold range confirming the PCR efficiencies of all primer pairs to be approximately equal (Ståhlberg et al. 2003), data were analyzed using the comparative $\Delta \Delta C_{\mathrm{T}}$ method (Livak \& Schmittgen 2001) calculating the difference between the threshold cycle $\left(C_{\mathrm{T}}\right)$ values of the target and reference gene of each sample and then comparing the resulting $\Delta C_{\mathrm{T}}$ values between different samples. In these experiments, mRNA not subjected to RT was used as a negative control to distinguish cDNA and vector or genomic DNA amplification.

Antibodies and western blot analysis

SK-OV-3 cells were lysed in RIPA buffer 1\% (v/v) Igepal CA$630,0 \cdot 5 \%(\mathrm{w} / \mathrm{v})$ sodium deoxycholate, $0 \cdot 1 \%(\mathrm{w} / \mathrm{v})$ SDS in PBS containing aprotonin and sodium orthovanadate. Aliquots containing $15 \mu \mathrm{g}$ proteins were resolved by $10 \%$ (w/v) SDSPAGE, followed by electrotransfer to a PVDF hybond (Amersham) membrane. Immunodetection was carried out

\begin{tabular}{|c|c|c|c|c|c|c|c|c|c|}
\hline 5'UTR & Exon 1 & 2 & 3 & 4 & 5 & 6 & 7 & 8 & 3 'UTR \\
\hline
\end{tabular}

ERß1

\begin{tabular}{|c|c|c|c|c|}
\hline $\mathrm{H}_{2} \mathrm{~N}-$ & $A F-1$ & DBD & LBD & AF-2 \\
\hline
\end{tabular}

$\operatorname{ER} \beta \delta 125$

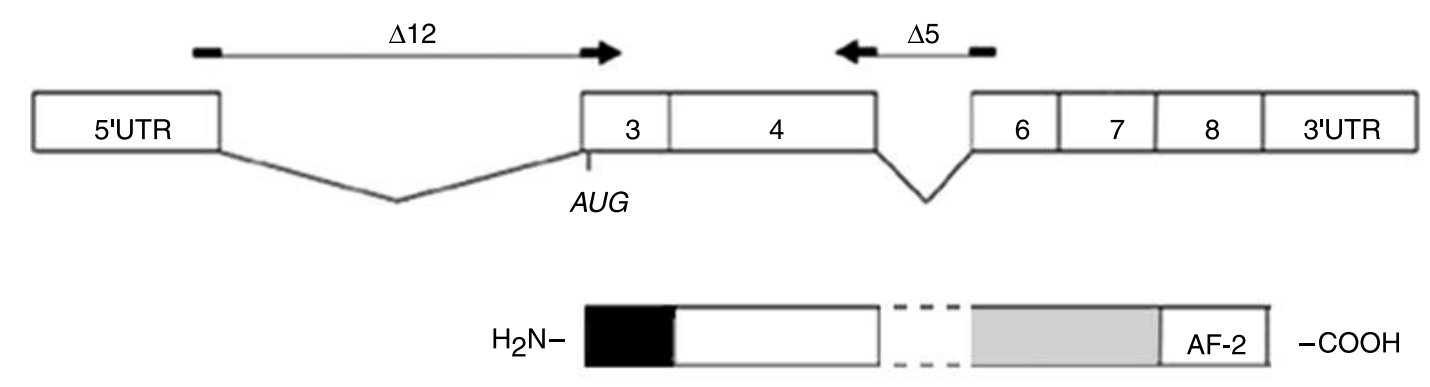

$\operatorname{ER} \beta \delta 1256$
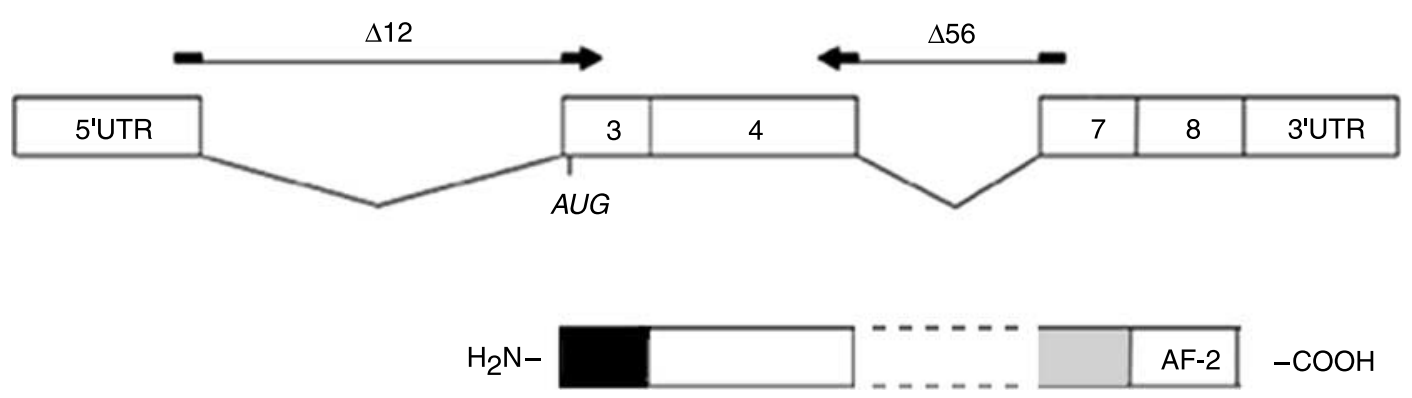

Figure $1 \mathrm{mRNA}$ and expected protein structure of the ER $\beta \delta 125$ and ER $\beta \delta 1256$ splice variants in comparison to ER $\beta 1$. Arrows indicate the position of PCR primers used in this study. UTR, untranslated region; AUG, translation initiation codon; DBD, DNA-binding domain; LBD, ligand-binding domain; AF-1/2, activation function 1/2. 
using ER $\beta$ antibody (GR-39, Oncogene) or $\beta$-actin antibody (8226, ABCAM, Cambridge, UK) diluted 1:5000 in PBS containing $5 \%$ skim milk $(\mathrm{w} / \mathrm{v})$ followed by horseradish peroxidase-conjugated secondary antibody, which was detected using a chemiluminescence (ECL) system (Amersham).

\section{Cell viability assay}

SK-OV-3 wild-type (WT) cells and SK-OV-3 clones cultured in DMEM containing $10 \%$ FCS or $1 \times$ SR 2 were seeded in 96-well plates in triplicates (1000 cells/well), and serum-free cultured cells were treated with $1 \mathrm{nM}$ E2 alone or in combination with $4-\mathrm{OH}$ TAM $(0 \cdot 5$ or $5 \mu \mathrm{M})$. After 72,96 , 120 , and $144 \mathrm{~h}$, relative numbers of viable cells were measured in comparison with the untreated control and the solvent control using the fluorimetrical, resazurin-based Cell Titer Blue assay (Promega) according to the manufacturer's instructions at $560_{\mathrm{Ex}} / 590_{\mathrm{Em}} \mathrm{nm}$ in a Victor3 multilabel counter (Perkin-Elmer, Waltham, MD, USA). Cell growth was expressed as percentage of the untreated medium control. Statistical analysis of the data was performed by one-way ANOVA using Prism 2.0 Software (Graph pad, San Diego, CA, USA), with statistical significance accepted at $P<0 \cdot 05$.

\section{Apoptosis assays}

SK-OV-3 WT cells and SK-OV-3 clones cultured in DMEM supplemented with $1 \times$ SR2 (Sigma) were seeded in 96-well plates $\left(5 \times 10^{3}\right.$ cells/well) and treated with $1 \mathrm{nM} \mathrm{E2,} 10 \mu \mathrm{M}$ 4-OH TAM or apoptosis inductor staurosporine $(0 \cdot 1 \mu \mathrm{M})$ as a positive control. After $6 \mathrm{~h}$ treatment, cellular apoptosis was determined by measurement of caspase 3 and 7 activity by means of the luminometric Caspase-Glo 3/7 assay (Promega) according to the manufacturer's protocol using a Victor3 multilabel counter (Perkin-Elmer). Additionally, apoptosis was measured by means of the Annexin V-FLUOS Staining Kit (Roche). Cells were treated with Annexin V and propidium iodide (PI) according to the manufacturer's protocol, and apoptotic cells exhibiting positive green Annexin V fluorescence but no red PI staining were counted. Cellular apoptosis was expressed as percentage of the untreated medium control or as percentage of the SK-OV-3 WT cells. Statistical analysis of the data was performed by one-way ANOVA using Prism 2.0 Software (Graph pad), with statistical significance accepted at $P<0 \cdot 05$.

\section{Wound-healing assay}

SK-OV-3 cells were plated in 6 -well dishes $\left(3 \times 10^{5}\right.$ cells/well) in DMEM/F12 containing $1 \times$ SR2 (Sigma). The next morning, cells were treated with $1 \mathrm{nM}$ E2 or ethanol as negative control. After $24 \mathrm{~h}$ of treatment, woundinduced migration was triggered by scraping the cells with a blue tip, and the scratch was pictured immediately (day 0 ). The cells were pictured again $48 \mathrm{~h}$ later. The percentage of wound filling was calculated by computer-aided measuring of the remaining gap space on the pictures using the software Adobe Photoshop Elements 2.0.

\section{Reporter gene assays}

SK-OV-3 and OVCAR-3 WT cells were seeded in 6-well plates in DMEM/F12 supplemented with $5 \%$ FCS $\left(4 \times 10^{5}\right.$ cell per well), $5 \mathrm{~h}$ later serum concentration was reduced to $1 \%$ and $0.5 \times$ serum-free SR 2 medium was added. The next day, the prior to transfection medium was changed to $1 \times$ SR 2 . Transfections were carried out mixing $10 \mu \mathrm{l}$ Transfectin reagent (Bio-Rad) in a total volume of $250 \mu \mathrm{l}$ OptiMEM medium with $5 \mu \mathrm{g}$ pEGFP$\mathrm{N} 2$ vector (Clontech) for easy visualization of transfection efficacy using a fluorescence microscope, $5 \mu \mathrm{g}$ pTAL-SEAP vector (Clontech) as positive control for the SEAP assay, or $10 \mu \mathrm{g}$ reporter gene vector pTAL-ERE-SEAP (Clontech). Generally, $5 \mu \mathrm{g} \mathrm{pSV}-\beta-G A L$ vector (Promega) was added to the transfection solution serving as internal control for transfection efficacy. $24 \mathrm{~h}$ after adding the $250 \mu \mathrm{l}$ transfection solution to the medium, cells were stimulated with $100 \mathrm{nM}$ E2 alone or in combination with $1 \mu \mathrm{M}$ 4-OH TAM in fresh DMEM/F12 containing $1 \times$ SR 2 . The next day, the medium was removed and $20 \mu \mathrm{l}$ of it was subjected to the Phospha-Light Assay (Applied Biosystem) for luminometric quantification of secreted SEAP protein in the culture supernatant according to the instructions of the manufacturer. Cells were lysed using the $\beta$-Glo Assay (Promega) and subjected to this assay for luminometric determination of transfected $\beta$-galactosidase enzyme as internal control for the transfection efficacy. Both luminometric SEAP and $\beta$-GAL quantification were carried out using a VICTOR 3 multilabel plate reader (Perkin-Elmer). To normalize the data, SEAP values are expressed in relation to the measured $\beta-G A L$ values.

\section{Results}

Expression of $E R \beta 1, E R \beta-\delta 125$, and $E R \beta-\delta 1256$ in human ovary and ovarian cancer

First, we examined whether ER $\beta 1$ and the exon-skipped ER $\beta$ splice variants (Fig. 1) cloned from human breast cancer cells (Treeck et al. 2007) were also expressed in ovary and in ovarian cancer. For this purpose, a cDNA pool from epithelial ovarian cancer tissue specimen and from normal ovary (Rapid-Scan Kit, Origene) was screened for ER $\beta 1$, ER $\beta \delta 125$, and ER $\beta \delta 1256$ transcripts by means of RT-PCR. To confirm specificity of amplification of the exon-skipped variants, a set of isoform-specific PCR primers was used annealing at the junction of the $5^{\prime}-\mathrm{UTR}$ and exon 3 (primer $\delta 12$ ) and the junction of exon 4 and 6 (primer $\delta 5$ ) or exon 4 and 7 (primer 856 ) respectively and identity of the resulting amplicons was confirmed by sequencing. ER $\beta 1$, the specific 438 bp ER $\beta-\delta 125$ amplicon and the 450 bp ER $\beta-\delta 1256$ cDNA fragment were detected both in normal ovary and in ovarian cancer tissue (Fig. 2a). In all samples, detection of $\beta$-actin generally was used as positive control (not shown). 

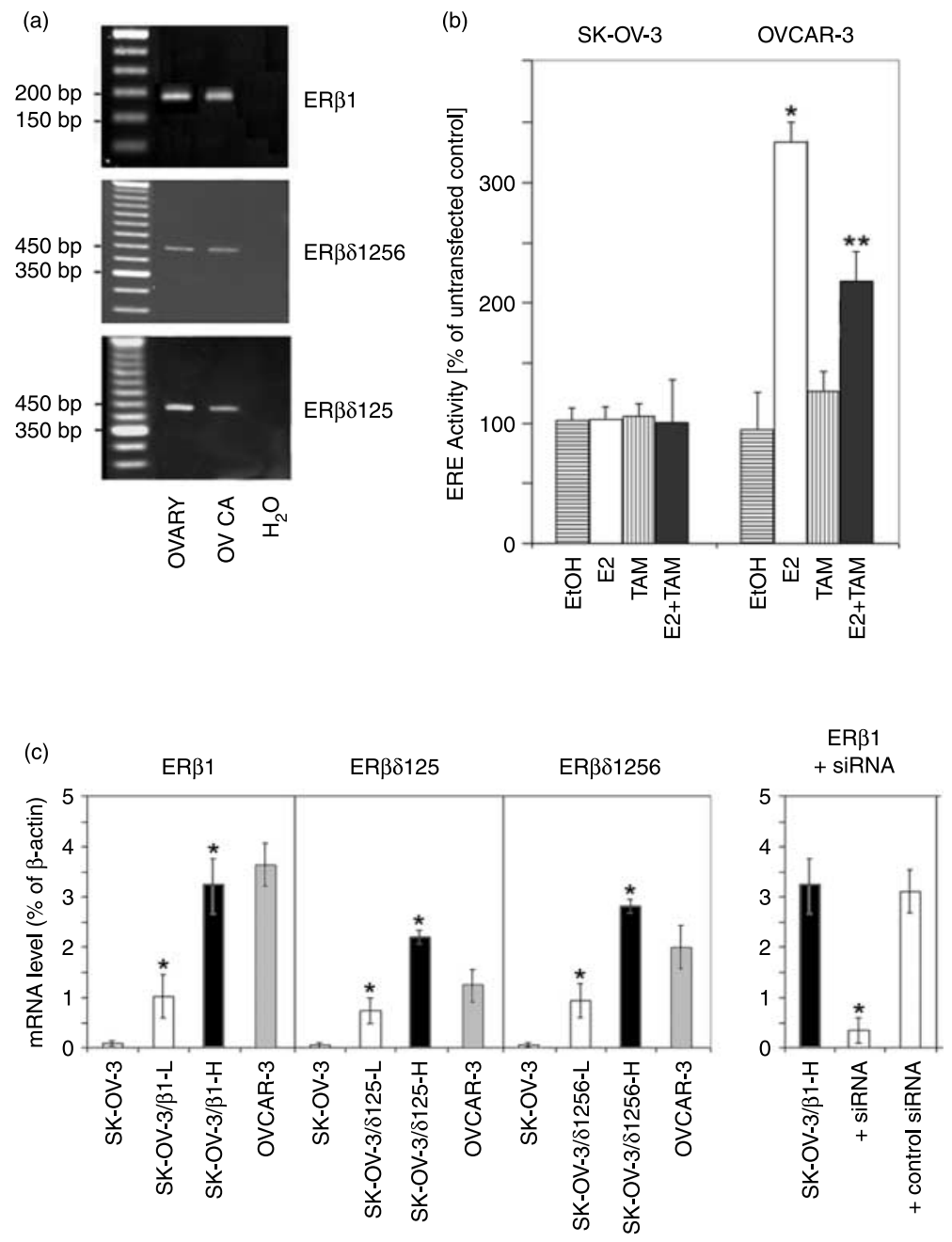

(d)

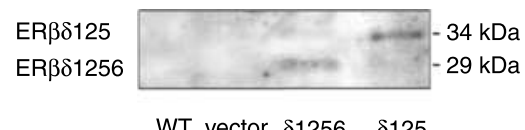

$\beta$-ACTIN

WT vector $\delta 1256 \quad \delta 125$

Figure 2 Expression of ER $\beta$ isoforms in ovarian cancer cells. (a) Detection of ER $\beta 1$, ER $\beta-\delta 1256$, and ER $\beta-\delta 125$ mRNA in samples (pooled, $n=$ 10) from normal human ovary and ovarian cancer tissues (OV CA) by means of RT-PCR. (b) Estrogen response of SK-OV-3 and OVCAR-3 cells: activation of estrogen-response elements (ERE) after stimulation with $1 \mathrm{nM} 17 \beta$-estradiol alone or in combination with $1 \mu \mathrm{M} 4$-OH TAM for $24 \mathrm{~h}$. ERE activation was determined by luminometric quantification of secreted SEAP protein by means of the Phospha Light Assay (Applied Biosystem). Cells were lysed using the Beta-Glo Assay (Promega) and subjected to this assay for luminometric determination of transfected $\beta$ galactosidase enzyme as internal control for the transfection efficacy. Both luminometric SEAPand $\beta$-GAL quantification were carried out using a VICTOR3 multilabel plate reader (Perkin-Elmer). To normalize the data, SEAP values are expressed in relation to the measured $\beta$-GAL values $(n=3)$. Data are expressed in percentage of the untreated (solvent EtOH) control. ${ }^{*} P<0.05$ versus untreated control. (c) Relative transcript levels of ER $\beta 1$ and the exon-deletion variants in ovarian SK-OV-3 and OVCAR-3 cells. In comparison to the wild-type cells, the relative mRNA levels detected after overexpression of the respective ER $\beta$ variant in SK-OV-3 cells and after siRNA-mediated knockdown of ER $\beta 1$ in SK-OV3/ER $\beta 1-H$ cells are shown. Specific ER $\beta$ mRNA levels of two clones $(L$ and $H)$ isolated after G418 selection were determined by means of real time RT-PCR using a Light Cycler device (Roche) in comparison to samples, which were not reversely transcribed as described in the Materials and Methods section and are expressed as percentage of the corresponding $\beta$-actin mRNA level $(n=3)$. SK-OV-3/ER $\beta 1$-H cells were treated with $30 \mathrm{nM}$ ER $\beta 1$ siRNA and negative control RNA for $24 \mathrm{~h}$ and ER $\beta 1$ level was detected (right panel). (d) Detection of the ER $\beta$ isoforms ER $\beta \delta 125$ and ER $\beta \delta 1256$ on protein level in transfected SK-OV-3 ovarian cancer cells. $15 \mu$ g protein of cell lysate isolated from SK-OV-3 wild-type (WT) cells, vector-transfected cells (vector) and SK-OV-3 clones stably expressing ER $\beta \delta 125$ and ER $\beta \delta 1256 \mathrm{mRNA}$ were loaded and resolved by $10 \%$ SDSPAGE. Detection of $\beta$-actin expression was used as a loading control, ER $\beta$ antibody GR39/Ab-2 (Oncogene) was used in a dilution of 1:10 000.

Heterologous expression of $E R \beta 1, E R \beta-\delta 125$, and $E R \beta-\delta 1256$ in $S K-O V-3$ cells and siRNA-triggered knockdown of $E R \beta 1$

To confirm estrogen-unresponsiveness of SK-OV-3 cells, we assessed ERE activation in this cell line and in OVCAR-3 cells by means of reporter gene assays. Stimulation by estradiol resulted in ERE activation in ER $\alpha$-positive OVCAR-3 cells, but not in SK-OV-3 ovarian cancer cells (Fig. 2b).

Given that real time PCR analysis of ER $\beta 1, E R \beta-\delta 125$ and ER $\beta-\delta 1256$ mRNA levels revealed a very weak expression of these receptor isoforms in SK-OV-3 cells (Fig. 2c), which was 20 - to 50-fold lower than in the pooled ovarian cancer samples 

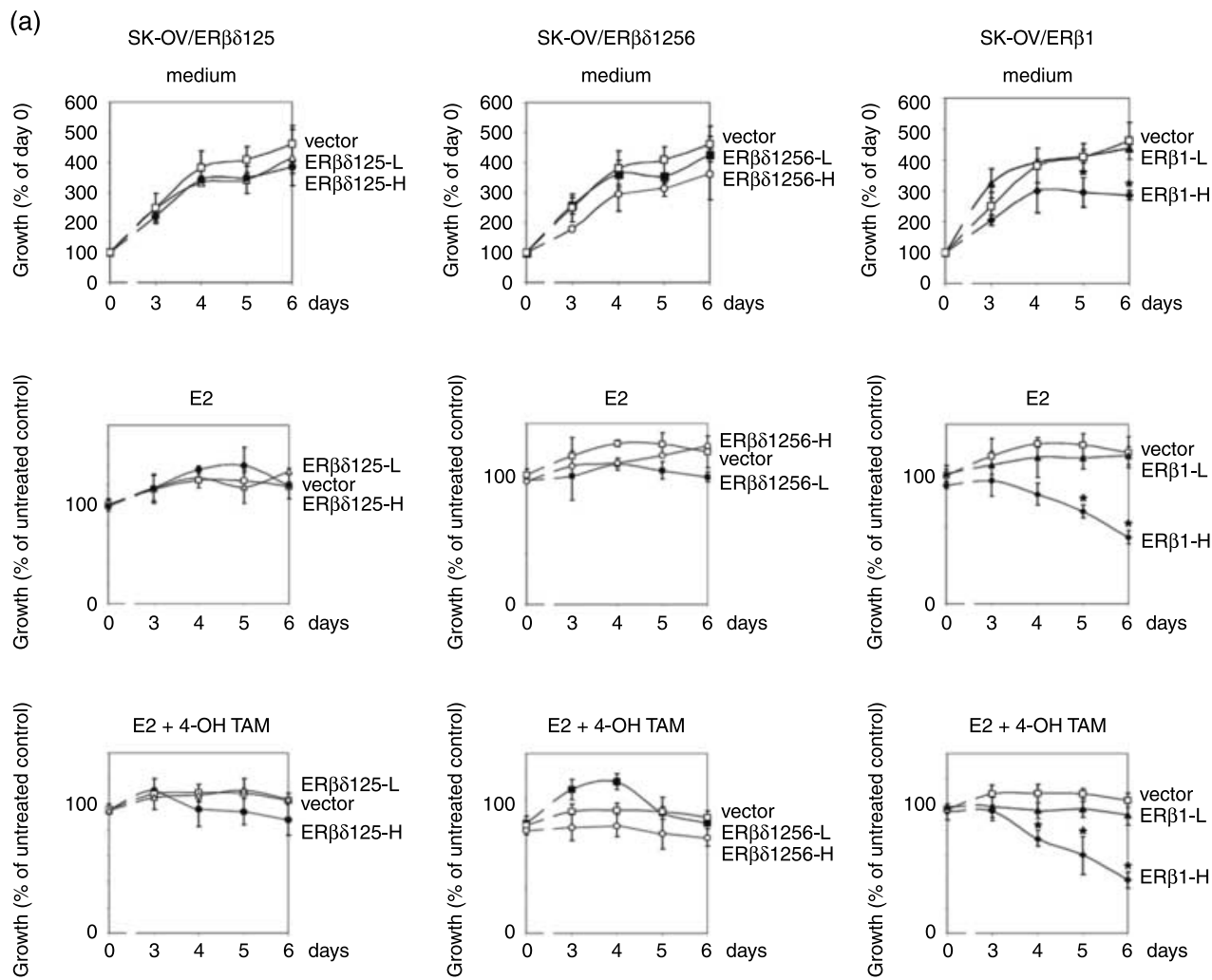

(b)
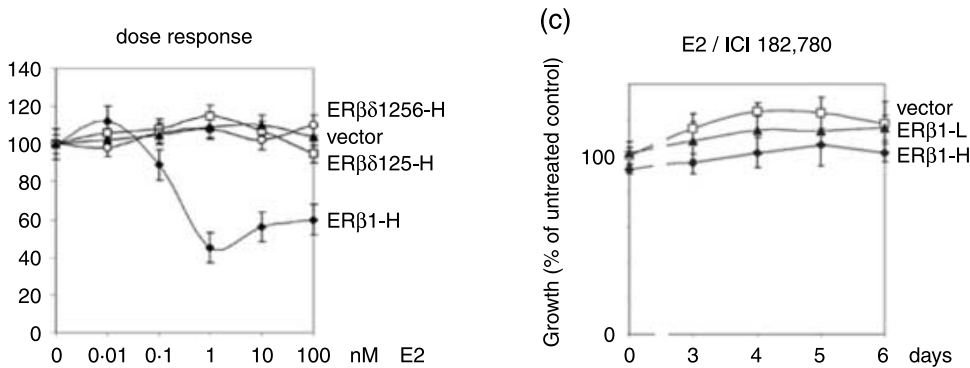

(d)
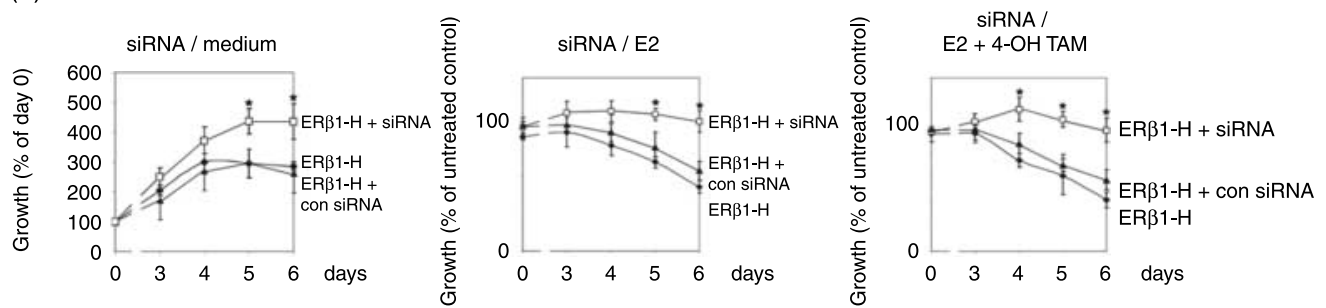

Figure 3 Cell growth of SK-OV-3 clones stably expressing ER $\beta 1$ or the exon-skipped isoforms. (a) Transfected SK-OV-3 cells overexpressing lower $(\mathrm{L})$ or higher $(\mathrm{H})$ levels of ER $\beta 1$, ERß $\delta 125$, or ER $\beta \delta 1256 \mathrm{mRNA}$ were cultured up to 6 days in serum-free medium in the absence of estradiol or supplemented with $1 \mathrm{nM} 17-\beta$ estradiol (E2) alone or in combination with $1 \mu \mathrm{M} 4-\mathrm{OH}$ tamoxifen (4-OH TAM). Cell growth was compared with mock-transfected cells (vector). Open square, SK-OV-3-vector control; black triangle, ERß1-L; black rhombus, ERß1-H; open triangle, ER $\beta \delta 125-\mathrm{L}$; black circle, ER $\beta \delta 125-\mathrm{H}$; black square, ER $\beta \delta 1256-\mathrm{L}$; open circle, ER $\beta \delta 1256-\mathrm{H}$. *P<0.01 versus vector-transfected control cells. (b) Dose-response analysis of the generated SK-OV-3 clones. Cells grown in serum-free medium were treated with the indicated concentrations of $17 \beta$-estradiol and cell growth was determined on day 6. (c) SK-OV-3 cells overexpressing ER $\beta 1$ were treated with $1 \mathrm{nM}$ 
(data not shown), we used this cell line to elucidate the function of ER $\beta 1$ and the exon-skipped ER $\beta$ splice variants in ovarian cancer cells by means of heterologous gene expression. SK-OV-3 cells were transfected with pTAR GET mammalian expression vectors (Promega) containing the coding region of ER $\beta 1, E R \beta-\delta 125$, or ER $\beta-\delta 1256$ or the original pTAR GET vector as negative control. After verification of their expression in transient transfection assays on mRNA level by means of RT-PCR (data not shown), SK-OV-3 clones stably expressing the transfected pTARGET derivatives were generated by G418 selection $(300 \mu \mathrm{g} / \mathrm{ml})$. About 6 weeks after transfection, 3-6 SK-OV-3 clones per derivative were isolated using cloning disks and propagated. In these clones, mRNA levels of ER $\beta 1$, $E R \beta-\delta 125$, or $E R \beta-\delta 1256$ respectively, was quantified in relation to $\beta$-actin expression by means of real time RT-PCR, avoiding false-positive signals from vector DNA by comparison to a sample, which was not reversely transcribed. Heterologous expression of ER $\beta$ isoforms in SK-OV-3 cells was additionally verified by sequencing of the amplified cDNA. SK-OV-3 clones mock transfected with the original pTARGET vector as negative control were identified by detection of mRNA transcribed from the neomycin resistance gene of this vector by means of RT-PCR (primers PTAR 1 and pTAR2). Two clones, $\mathrm{H}$ (higher expression) and L (lower expression) from SK-OV-3/ $\beta 1$, SK-OV-3/ס125, SK-OV-3/ $\delta 1256$ cells exhibiting ER $\beta$-isoform mRNA levels similar to the ovarian cancer samples, were chosen for further characterization. Additionally, we chose an RNAi approach to confirm specificity of the observed ER $\beta 1$ effects on proliferation and apoptosis. We used siRNA specific for ER $\beta 1$ to knockdown ER $\beta 1$ expression in SK-OV-3/ER $\beta 1$ $\mathrm{H}$ cells. Transfection of these cells with $30 \mathrm{nM}$ ER $\beta 1$ siRNA resulted in a significant reduction of ER $\beta 1 \mathrm{mRNA}$ levels down to $10 \%$ of the respective level in control cells (transfected with scrambled siRNA; Fig. 2c). For the first time we succeeded in detection of the $\delta 125$ and $\delta 1256$ isoforms on protein level in transfected SK-OV-3 clones by means of western blot analysis. The use of ER $\beta$ antibody GR39/Ab-2 (Oncogene) succeeded in detection of weak bands of expected size in transfected SK-OV-3 cells, but not in WT or vectortransfected cells, confirming heterologous expression of the exon-skipped isoforms on protein level (Fig. 2d).

Proliferation of SK-OV-3 cells heterologously expressing ER $\beta 1$, $E R \beta-\delta 125$ or $E R \beta-\delta 1256$

Given that ERs are known to regulate cellular proliferation by different molecular mechanisms, we examined the effect of heterologous ER $\beta$ isoform expression on cellular proliferation of SK-OV-3 cells. For this purpose, both vectortransfected and ER $\beta$-transfected SK-OV-3 cells were cultured in serum-free SR2 medium and treated with E2 $(1 \mathrm{nM})$ alone or in combination with $4-\mathrm{OH}$ TAM $(1 \mu \mathrm{M})$ for up to 6 days. In serum-free culture medium, SK-OV-3 cells containing higher ER $\beta 1$ transcript levels exhibited a significantly reduced proliferation if compared with vectortransfected cells even in the absence of E2 $(P<0 \cdot 01$ versus vector control). This effect was not observed in cells expressing lower ER $\beta 1 \mathrm{mRNA}$ levels or the exon-skipped variants. Addition of $1 \mathrm{nM}$ E2, a concentration, which was observed to exert the strongest effect on cell growth of ER $\beta 1$ $\mathrm{H}$ cells (Fig. 3b), further slowed cell growth of SK-OV-3 cells stably expressing higher levels of ER $\beta 1 \mathrm{mRNA}$, but did not affect proliferation of SK-OV-3 cells expressing $\delta 125$ or $\delta 1256$ transcript isoforms or lower levels of ER $\beta 1$. Addition of 4-OH TAM to the E2-containing culture medium was not able to affect E2-triggered growth inhibition in SK-OV-3 cells overexpressing ER $\beta 1$ (Fig. 3a). In contrast, addition of pure antiestrogen ICI $182780(100 \mathrm{nM})$ significantly inhibited the effect of E2 on growth of these cells (Fig. 3c). To confirm specificity of the observed antiproliferative effect of ER $\beta 1$ expression, we used an RNAi approach to knockdown ER $\beta 1$ expression in SK-OV-3/ER $\beta 1-\mathrm{H}$ cells. Growth analysis of siRNA-treated cells exhibiting significantly reduced ER $\beta 1$ levels (Fig. 2c) revealed that ER $\beta 1$ knockdown reverted the growth inhibitory effect of ER $\beta 1$ overexpression (Fig. 3d).

\section{Apoptosis of SK-OV-3 cells heterologously expressing ER $\beta 1$,} $E R \beta-\delta 125$, or $E R \beta-\delta 1256$

The decreased cell growth observed in SK-OV-3 cells transfected with ER $\beta$ isoforms could result not only from cell-cycle blockage, but also from increased apoptosis. To examine the effect of ER $\beta$ isoforms on apoptosis of SK-OV-3 cells, basal caspase $3 / 7$ activity was analyzed. We observed significantly increased caspase 3/7 activation in SK-OV-3 cells expressing higher levels of ER $\beta 1$ mRNA grown in serumfree medium even in the absence of $\mathrm{E} 2$, but not in cells expressing lower levels of ER $\beta 1$ or the exon-skipped isoforms. Addition of E2 (Fig. 4a) or 4-OH TAM (not shown) did not affect the increased apoptosis of SK-OV-3 cells overexpressing ER $\beta 1$. In two of four experiments, we additionally performed experiments comparing the apoptotic cell membrane phosphatidylserine translocation in the different SK-OV-3 clones by means of double staining with

estradiol in combination with $100 \mathrm{nM} \mathrm{ICI} 182$ 780. Open square, SK-OV-3-vector control; black triangle, ERß1-L; black rhombus, ER $\beta 1-\mathrm{H}$. (d) SK-OV-3 cells overexpressing ER $\beta 1$ were treated with ER $\beta 1$ siRNA $(30 \mathrm{nM})$ and effects on cell growth were measured. Open square, SK-OV-3/ER $\beta 1-H$ treated with ER $\beta 1$ siRNA; black triangle, SK-OV-3/ER $\beta 1-H$ treated with scrambled control siRNA; black rhombus, SK-OV$3 /$ ER $\beta 1-\mathrm{H}$ transfected without siRNA. ${ }^{*} P<0 \cdot 01$ versus control siRNA transfected cells. Generally, relative viable cell numbers were measured using the resazurin-based Cell Titer Blue fluorescence assay as described in the Materials and Methods section on day 0, 3, 4, 5, and 6. Viable cell numbers are expressed as indicated in percentage of day 0 or in percentage of the untreated control. Results were obtained from four separate experiments and are expressed as means \pm s.D. 
Annexin V and PI confirming the results from the caspase assays (data not shown).

To confirm specificity of the observed apoptotic effect of ER $\beta 1$ on SK-OV-3 ovarian cancer cells, again we used an RNAi approach. SK-OV-3/ER $\beta 1-\mathrm{H}$ cells treated with ER $\beta 1$ siRNA $24 \mathrm{~h}$ prior to apoptosis detection and tested for ER $\beta 1$ knockdown to about 15\% (Fig. 2c) exhibited a significantly reduced apoptosis when compared with mocktransfected cells (Fig. 4b).

\section{Motility of SK-OV-3 cells heterologously expressing ERß1, $E R \beta-\delta 125$, or $E R \beta-\delta 1256$}

Because estrogen signaling is known not only to affect cell growth and apoptosis, but also cellular migration, it was important to determine whether ER $\beta 1$ or the exon-skipped ER $\beta$ isoforms could also affect motility of SK-OV-3 ovarian cells. For this purpose, we performed wound healing assays (Fig. 5a). In serum-free medium, SK-OV-3 WT and vector transfected control cells had filled about $75 \%$ of the wound after 4 days. In contrast, SK-OV-3 cells expressing higher levels of ER $\beta 1$ exhibited significantly slower migration ability as they filled only about $5 \%$ of the gap. SK-OV-3 cells expressing ER $\beta \delta 125$, high levels of ER $\beta \delta 1256$ or low levels of ER $\beta 1$ also exhibited a significantly diminished motility as they filled about $40-50 \%$ of the wound (Fig. 5b). Migration of SK-OV-3 cells expressing lower levels of ER $\beta \delta 1256$ did not differ from WT or control cells. The motility of all SK-OV-3 clones was not affected by treatment with $1 \mathrm{nM}$ E2.

\section{Expression of estrogen-responsive genes in SK-OV-3 cells} heterologously expressing $E R \beta 1, E R \beta-\delta 125$, or $E R \beta-\delta 1256$

Given that ERs are ligand-inducible transcription factors directly regulating gene transcription, we studied the effect of ER $\beta 1$ and the exon-skipped ER $\beta$ splice variants on expression of 15 estrogen-responsive genes in SK-OV-3 cells (progesterone receptor (PR), cyclin D1, CDK2, autotaxin, PS2, ER $\alpha$, FAS ligand, HER2, cathepsin D, EGFR, IGFBP-4, WISP-2, p21(WAF1), cyclin A2, and fibulin 1c). For this purpose, we analyzed expression of these genes in WT, control, and ER $\beta$-transfected SK-OV-3 cells cultured in serum-free medium ( $\pm 1 \mathrm{nM} \mathrm{E} 2$ for $24 \mathrm{~h}$ ) on mRNA level by means of real time RT-PCR.

Three of the analyzed genes, p21(WAF1), cyclin A2, and fibulin-1c exhibited altered mRNA levels in ER $\beta 1$ transfected SK-OV-3 ovarian cancer cells (Fig. 6). In SK-OV-3 cells overexpressing ER $\beta 1$, the up to fourfold elevated basal p21(WAF1) transcript levels were further increased after addition of E2 or 4-OH TAM. In SK-OV-3 cells expressing the $\delta 1256$ isoform or higher levels of the $\delta 125$ isoform, p21(WAF1) levels were also slightly increased, but were not affected by treatment with E2 or tamoxifen. In contrast, cyclin A2 mRNA level was decreased in SK-OV-3/ ER $\beta 1-\mathrm{H}$ cells in the absence of $\mathrm{E} 2$, and mRNA levels of this gene were further reduced after addition of E2 or $4-\mathrm{OH}$
TAM. Fibulin-1c transcript levels were fourfold elevated in SK-OV-3 cells expressing higher levels of ER $\beta 1$, and were further increased after treatment with E2 or tamoxifen.

Irrespective of estrogen or tamoxifen treatment, we did not observe any significant differences between the different clones and WT or vector-transfected SK-OV-3 cells regarding the expression of PR, cyclin D1, CDK2, autotaxin, PS2, ER $\alpha$, FAS ligand, HER2, cathepsin D, EGFR, IGFBP-4, or WISP-2.

\section{Discussion}

The aim of this study was to determine the extent to which ER $\beta 1$ and two of its exon-skipped isoforms modulate basic features of SK-OV-3 ovarian cancer cells like proliferation, motility and apoptosis, and to study changes in gene expression as potential underlying molecular mechanism. Recently, we have identified the two novel exon-skipped ER $\beta$ transcript variants $E R \beta-\delta 125$ and $E R \beta-\delta 1256$ in human breast cancer cells (Treeck et al. 2007). In this study, we detected ER $\beta 1, E R \beta-\delta 125$, and ER $\beta-\delta 1256$ transcripts both in human ovary and ovarian cancer tissue, but we did not measure a notable expression of these ER $\beta$ types in SK-OV-3 ovarian cancer cells. In contrast to other ovarian adenocarcinoma lines like OVCAR-3 or BG-1 expressing functional $\mathrm{ER} \alpha$ and other steroid hormone receptors like PR and AR, or normal ovarian epithelial cells, this cell line derived from an epithelial ovarian tumor is estrogen-unresponsive and HER2-overexpressing, and represents a relatively aggressive and fast growing ovarian cancer cell type (Lau et al. 1999). Our data demonstrating ERE activation by E2 in OVCAR-3, but not in SK-OV-3 cells confirm estrogen unresponsiveness of this cell line on molecular level.

In this study, we stably introduced cDNA coding for ER $\beta 1, E R \beta-\delta 125$, and ER $\beta-\delta 1256$ into SK-OV-3 cells to study the function of ER $\beta$ in this ovarian cancer model. For further characterization, we have chosen not the stably transfected clones exhibiting the highest expression levels, but the ones with lower overexpression levels comparable with the respective expression we measured in OVCAR-3 cells.

Several in vitro studies show evidence that $\operatorname{ER} \beta$ may negatively regulate cellular proliferation, promote apoptosis and thus may have a protective role in normal breast and prostate. The same studies also suggested that antitumoral effects of ER $\beta$ are not necessarily dependent on the presence of ER $\alpha$ (Brandenberger et al. 1998, Lazennec et al. 2001, Cheng et al. 2004). Supporting these reports, in this study, we demonstrate that ER $\beta$ exerts antitumoral effects on SK-OV-3 ovarian cancer cells not expressing functional ER $\alpha$ (Lau et al. 1999). A loss of $E R \beta$ expression or increased $E R \alpha / E R \beta$ ratio in epithelial ovarian cancer as compared with normal tissues has been reported consistently by several groups (Brandenberger et al. 1998, Pujol et al. 1998, Rutherford et al. 2000). A loss of ER $\beta$ expression could thus constitute a crucial step in ovarian carcinogenesis and hormone unresponsiveness. 
(a)

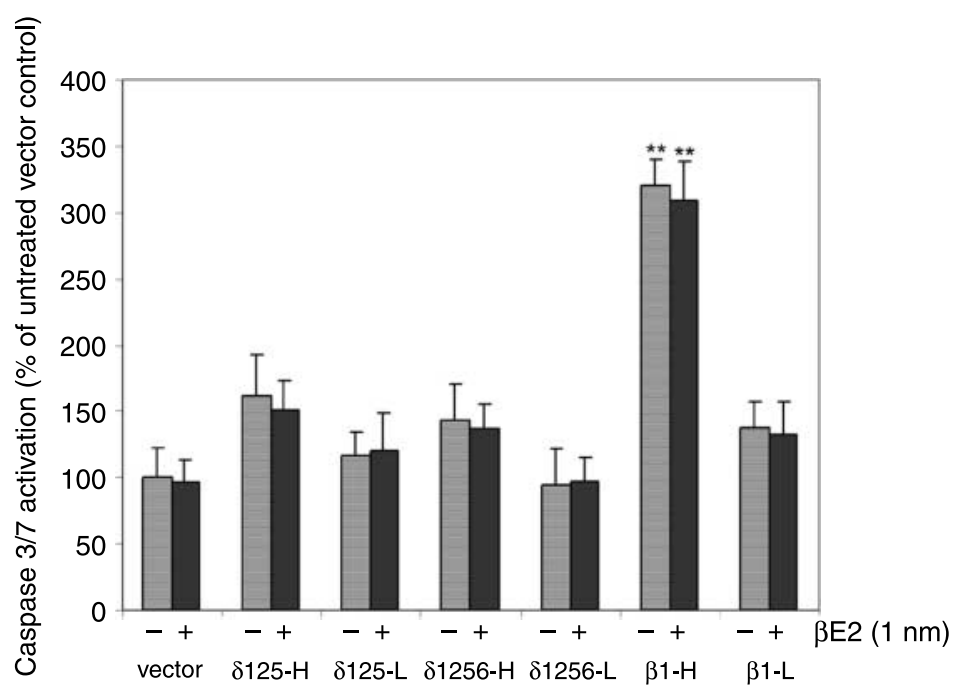

(b)

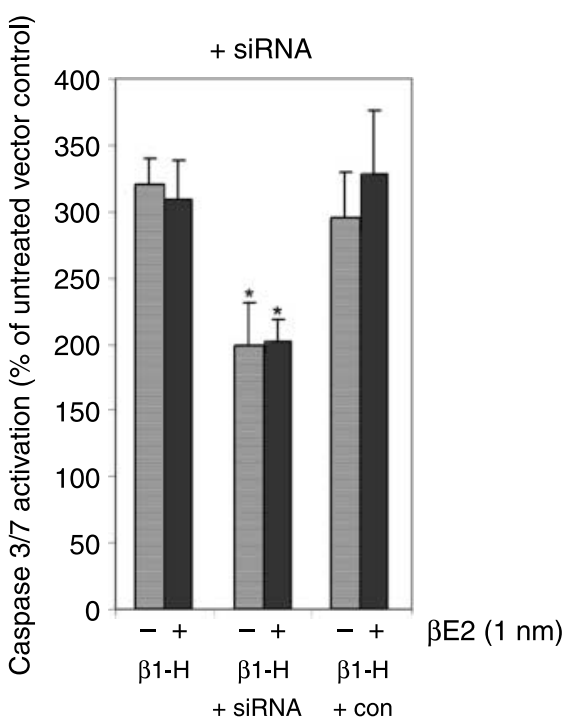

Figure 4 Caspase 3/7 activity in SK-OV-3 cells stably expressing ER 31 or the splice variants. (a) Vector-transfected SK-OV-3 cells (vector) and ER $\beta$-transfected SK-OV-3 clones were grown under serum-free conditions $\pm 1 \mathrm{nM}$ E2 and basal apoptosis was determined (b) SK-OV-3/ER $\beta 1$ $\mathrm{H}$ cells were treated with ER $\beta 1$ siRNA or scrambled control siRNA prior to apoptosis detection. Cells were subjected to a luminometric caspase 3/7 activation assay as described in the materials and methods section. Data are expressed in percentages of the untreated vector control. Results were obtained from four separate experiments and are expressed as means $\pm \mathrm{s}, \mathrm{D} .{ }^{*} P<0 \cdot 05$ versus untreated vector control cells, ${ }^{* *} P<0 \cdot 01$ versus untreated vector control cells.

However, the role of ER $\beta$ in ER $\alpha$-positive or -negative ovarian cancer cells is not completely understood. In this regard, the specific role of $E R \beta$ splice isoforms also remains unclear, though many ER $\beta$ splice variants are expressed in ovary and ovarian cancer (Poola et al. 2002a,b). Three different $\mathrm{ER} \beta$ variant mRNAs that have deletions in exon 5 or 6 or exons $5 / 6$ have been identified in human breast, uterus, and ovarian tissues (Lu et al. 1998, Vladusic et al. 1998, Speirs et al. 2000). A recent study examined the function of one of these exon-skipped variants, ER $\beta-\delta 5$, suggesting that this isoform might act as a dominant negative receptor on $\operatorname{ER} \alpha$ and ER $\beta$ pathways (Helguero et al. 2005). In another study, an ER $\beta$ isoform lacking the exons 2, 5, and 6 was identified and it was stated that deletion of these exons would cause a frame shift mutation resulting in premature termination of translation (Poola et al. 2002a,b). The exonskipped variants $E R \beta-\delta 125$ and $E R \beta-\delta 1256$ we examined here use a different translation initiation codon in the beginning of exon 3 allowing translation in the same reading frame as ER $\beta 1$. The proteins coded by these variants are predicted not to contain the AF-1 domain mediating the ligand-independent transcriptional activity of ER $\beta$ and are predicted to have deletions both in the DBD and LBD. Thus, it is expected that both the ligand-dependent and ligandindependent activity of the deduced proteins are significantly diminished.

SK-OV-3 ovarian cancer cells are reported to be estrogenunresponsive because they express a truncated, dysfunctional $\mathrm{ER} \alpha$, and were described to express very low levels of $\operatorname{ER} \beta$
(Jones et al. 1994, Lau et al. 1999). Our findings demonstrating a reduced proliferation of SK-OV-3 cells stably expressing higher levels of ER $\beta 1$ even in absence of E2 are in agreement with previous studies showing ligandindependent antiproliferative effects of this receptor on tumor cells of different origin (Lazennec et al. 2001, Cheng et al. 2004). Growth of SK-OV-3 cells overexpressing ER $\beta 1$ was further reduced by E2 also demonstrating a ligand-dependent action of this receptor in our cellular system. The results of our RNAi approach demonstrating a reversion of ER $\beta 1$ triggered growth inhibition clearly confirm the antiproliferative action of this receptor in SK-OV-3 ovarian cancer cells. The absence of any significant effect of E2 or tamoxifen on SK-OV-3 cells stably expressing the exon-skipped variants could be explained by their LBD deletions, which are expected to impair ligand binding.

It was also of great interest to analyze the effects of ER $\beta 1$ and the two exon-skipped isoforms on apoptosis, because cell growth results from the balance of both cell cycle events and apoptosis regulation. We decided to examine the intrinsic apoptotic pathway, because ER $\beta$ previously was reported to promote apoptosis in a caspase 3-dependent manner in breast and prostate cancer cells (Cheng et al. 2004, Mak et al. 2006). And in fact, introduction of ER $\beta 1$ in ovarian cancer cells led to an increased basal apoptosis rate as shown both by caspase 3 and 7 activation and Annexin V staining. Apoptosis rate was not significantly elevated in SK-OV-3 cells expressing the exon-skipped isoforms, suggesting that the AF-1 or LBD domain are important for the apoptotic effect of ER $\beta$. 
(a) medium - day 0

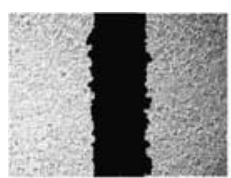

medium - day 4
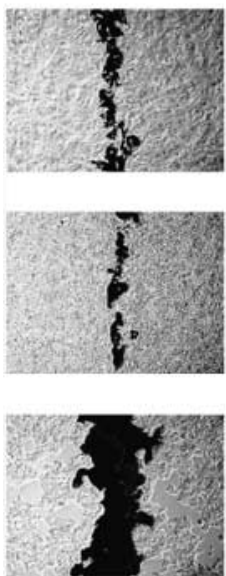

ER $\beta 1-H$

Vector
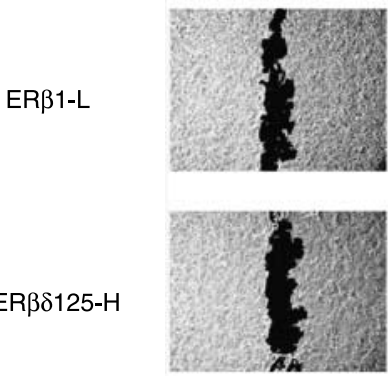

ER $\beta \delta 125-\mathrm{H}$

ER $\beta 1-L$

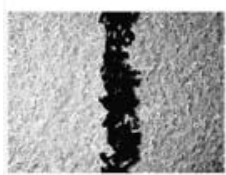

ER $\beta \delta 125-L$

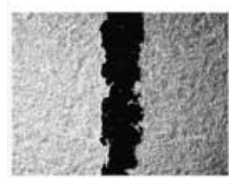

ER $\beta \delta 1256-L$

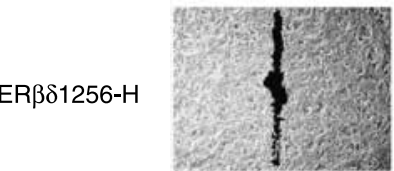

$+\beta \mathrm{E} 2$ - day 0

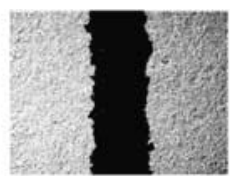

$+\beta E 2$ - day 4
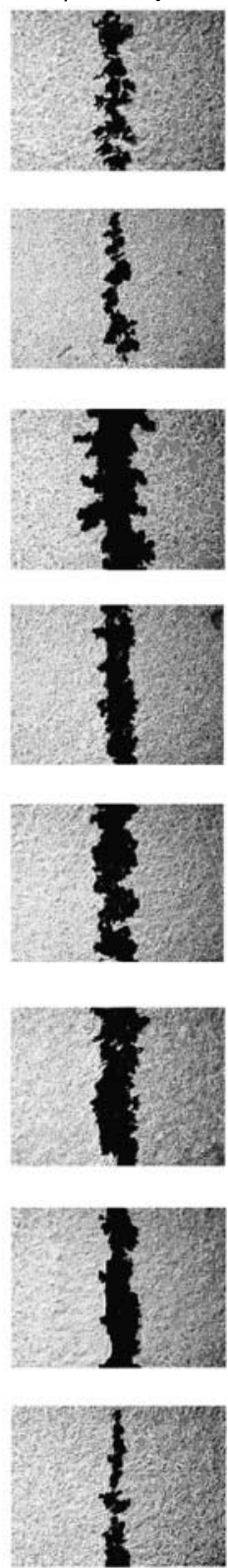

(b)

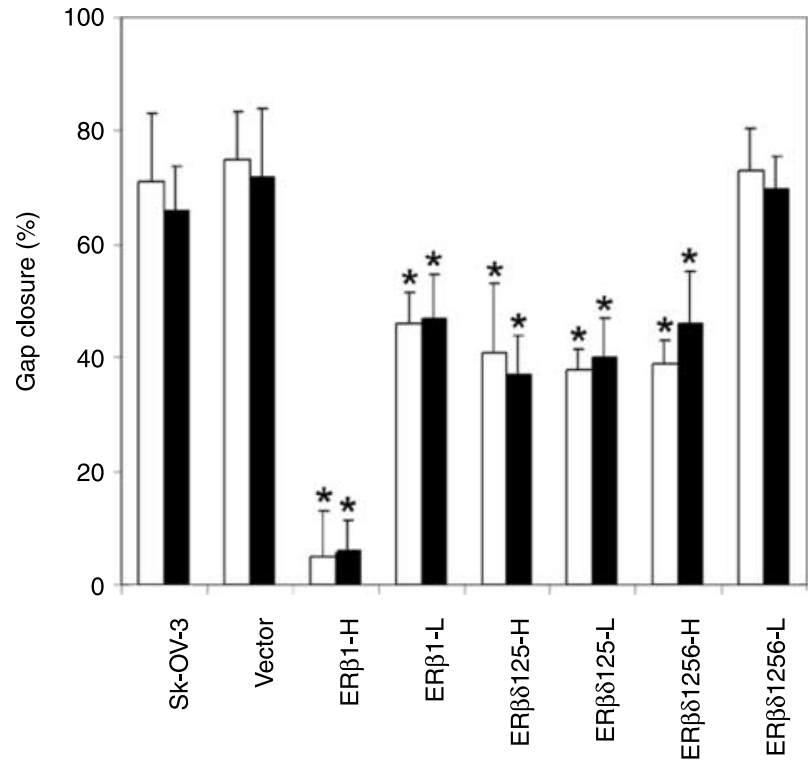

Figure 5 Motility of SK-OV-3 cells heterologously expressing ER $\beta 1$ or the exon-skipped isoforms. Cells cultured in serum-free medium were seeded in 6-well dishes, treated with $\mathrm{E} 2$ or solvent $\mathrm{EtOH}$ and wound healing was induced by a scratch with a blue pipet tip. (a) Cells were pictured directly after wounding (shown is a representative result) and 4 days later. (b) The percentage of wound filling was calculated by measuring the remaining gap space on the pictures. Results were obtained from three separate experiments and are expressed as means \pm s.D. $* P<0 \cdot 05$ versus vector-transfected control cells. 


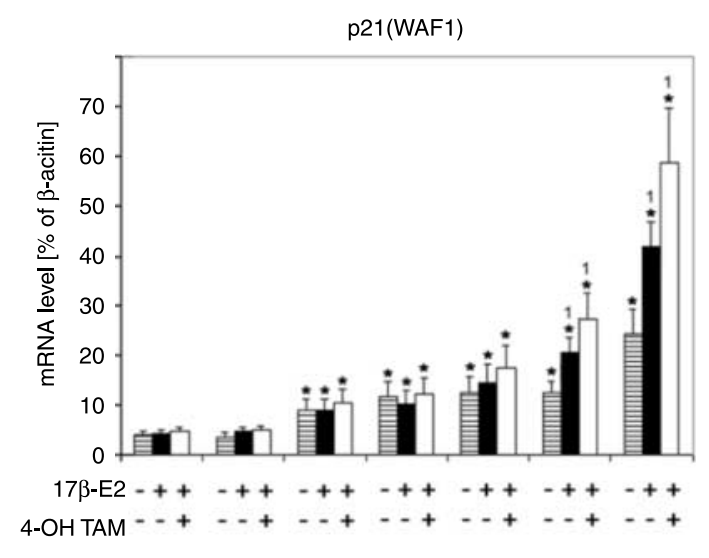

Vector $\delta 125-\mathrm{L} \quad \delta 125-\mathrm{H} \quad \delta 1256-\mathrm{L} \quad \delta 1256-\mathrm{H} \quad \beta 1-\mathrm{L} \quad \beta 1-\mathrm{H}$

Fibulin 1C

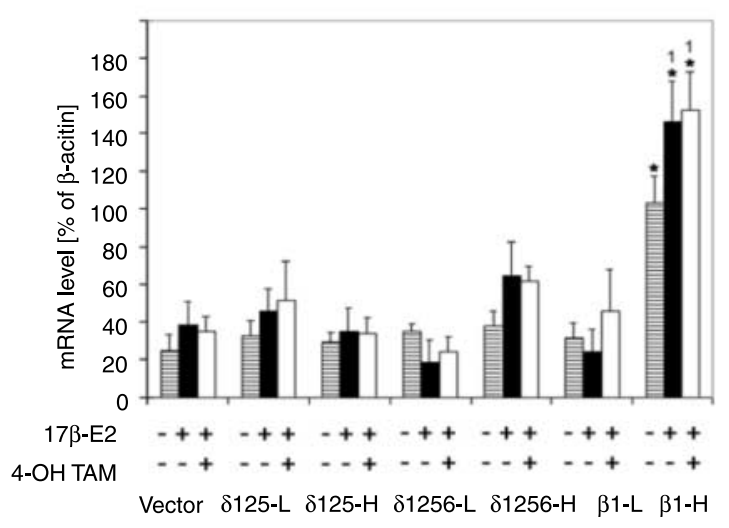

Cyclin A2

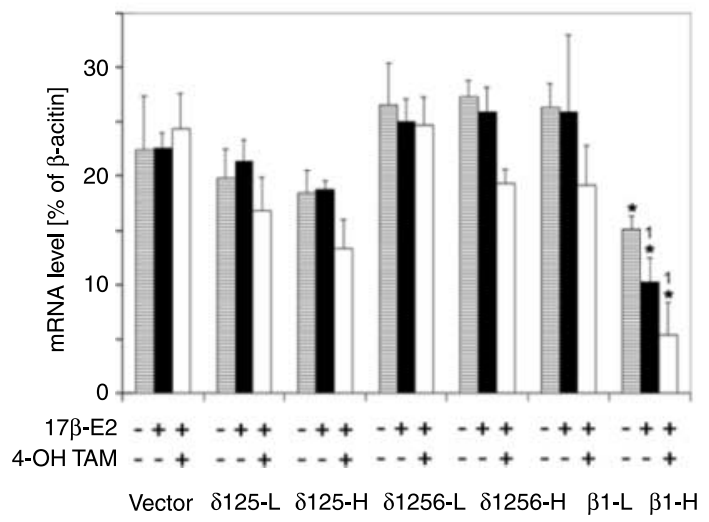

Figure 6 Transcript levels of three genes in SK-OV-3 cells heterologously expressing ER $\beta 1$ or its exon-skipped isoforms. SK-OV-3 vector-transfected (vector) or ER $\beta$-transfected cells cultured in serumfree medium were treated with $1 \mathrm{nME2}$ alone or in combination with $1 \mu \mathrm{M} 4-\mathrm{OH}$ tamoxifen $24 \mathrm{~h}$ prior to total RNA isolation. Shown are the relative expression levels as determined by real time RT-PCR expressed in percentage of the corresponding $\beta$-actin transcript level. Results were obtained from five separate experiments and are expressed as means \pm s.D. ${ }^{*} P<0 \cdot 05$ versus SK-OV-3 wild-type and vector transfected control cells. ${ }^{* 1} P<0 \cdot 05$ versus untreated.
Interestingly, in SK-OV-3 cells overexpressing ER $\beta 1$ we did not observe any effect of E2 or tamoxifen on apoptosis suggesting that ER $\beta$ induction of apoptosis in this ovarian cancer cell line is a ligand-independent effect. The data from our siRNA approach demonstrating apoptosis reduction after treatment of SK-OV-3/ER $\beta 1-H$ cells with ER $\beta 1$ siRNA clearly supports specificity of apoptotic ER $\beta 1$ action in this ovarian cancer model.

We also investigated the potential modulation of motility by ER $\beta 1$ and both exon-skipped isoforms, as another key event occurring during tumor development. We indeed observed that ER $\beta 1$ drastically inhibits motility of the ovarian cancer cell line as observed previously in ER $\alpha$-negative breast and prostate cancer models exogenously expressing ER $\beta$ (Lazennec et al. 2001, Cheng et al. 2004). Again, these effects were estrogen-independent and motility of ER $\beta-\delta 125-$ and ER $\beta-\delta 1256$-transfected SK-OV-3 cells was altered only marginally suggesting that the exons deleted in both variants are important to confer ER $\beta$ inhibition of motility.

Little is known about the gene regulatory function of $\operatorname{ER} \beta$ in ovarian tissue. To analyze the molecular mechanisms underlying the observed alterations in proliferation, apoptosis, and motility of SK-OV-3 ovarian cancer cells expressing higher levels of ER $\beta 1$, we examined expression of a set of 15 estrogen-responsive genes on mRNA level. Even in the absence of E2, transcript levels of cell cycle inhibitor p21(WAF1) were strongly elevated in ER $\beta 1$-expressing cells and to a smaller extent also in SK-OV-3 cells expressing the exon-skipped isoforms, suggesting that $E R \beta$ is able to increase p21(WAF1) levels in a ligand-independent manner. Only in SK-OV-3 cells expressing full-length ER $\beta 1$, p21(WAF1) transcript levels were further elevated after treatment with E2 alone or in combination with 4-OH TAM, supporting previous studies suggesting an involvement of p21(WAF1) in cellular estrogen response (Planas-Silva \& Weinberg 1997, Thomas et al. 1998). Given that our results demonstrate that $\mathrm{p} 21$ (WAF1) mRNA level is increased in Sk-OV-3 cells expressing higher levels of ER $\beta 1$ and, which exhibit a reduced cell growth, it is tempting to speculate that p21(WAF1) might be a key mediator of the antiproliferative effect of ER $\beta 1$ in this ovarian cancer model.

Cyclin A2 is a cell cycle regulator, which is known to be estrogen responsive (Vendrell et al. 2004). The observed reduction of cyclin A2 mRNA levels in SK-OV-3 cells expressing ER $\beta 1$ could be another molecular mechanism underlying the growth inhibitory action of this receptor on SK-OV-3 cells. Downregulation of cyclin A2 in SK-OV-3 cells overexpressing ER $\beta 1$ after treatment with E2 clearly corresponds with the observed growth inhibitory effects.

The third gene exhibiting altered transcript levels in ER $\beta 1$-overexpressing SK-OV-3 cells was fibulin-1c, an extracellular matrix protein, which is overexpressed in epithelial ovarian and breast cancers and is involved in the regulation of cellular motility (Hayashido et al. 1998). Previous studies demonstrated that in ER $\alpha$-positive ovarian and breast cancer cell lines, fibulin-1c mRNA levels are 
markedly increased by estrogens (Moll et al. 2002, Bardin et al. 2005). Our data demonstrate that heterologous expression of ER $\beta 1$ in ovarian cancer cells also is able to strongly increase fibulin-1c transcript levels even in absence of functional ER $\alpha$ or E2, suggesting that the regulation of fibulin-1c by ER pathways is more complex than assumed. Indeed, recent studies reported that fibulin-1c is a gene, which is estrogenresponsive not through classical ER $\alpha$ binding to ERE, but by E2- triggered activation of specificity protein 1 binding sites (Moll et al. 2002). Thus, the observed upregulation of fibulin 1c expression in SK-OV-3/ER $\beta 1-\mathrm{H}$ cells could be at least one molecular mechanism underlying the decreased motility of these cells.

In this study, we analyzed the functions of ER $\beta 1$ and two exon-skipped ER $\beta$ splice isoforms by means of heterologous gene expression in estrogen-unresponsive SK-OV-3 ovarian cancer cells. Particularly overexpression of ER $\beta 1$ exerted strong antitumoral effects on SK-OV-3 cells in terms of inhibition of growth and motility and induction of apoptosis, accompanied by specific changes in gene expression. Our results clearly suggest that the tumor suppressor function of $\mathrm{ER} \beta 1$ in ovarian cancer cells is not necessarily dependent on ER $\alpha$ expression.

\section{Acknowledgements}

We thank Angelika Vollmer, Bettina Ederhofer and Helena Houlihan for their expert technical assistance. The authors declare that there is no conflict of interest that would prejudice the impartiality of this scientific work.

\section{References}

Anderson GL, Judd HL, Kaunitz AM, Barad DH, Beresford SA, Pettinger M, Liu J, McNeeley SG \& Lopez AM 2003 Effects of estrogen plus progestin on gynecologic cancers and associated diagnostic procedures: the women's health initiative randomized trial. JAMA 290 1739-1748.

Bardin A, Moll F, Margueron R, Delfour C, Chu ML, Maudelonde T, Cavailles V \& Pujol P 2005 Transcriptional and posttranscriptional regulation of fibulin-1 by estrogens leads to differential induction of messenger ribonucleic acid variants in ovarian and breast cancer cells. Endocrinology 146 760-768.

Brandenberger AW, Tee MK \& Jaffe RB 1998 Estrogen receptor alpha (ER-alpha) and beta (ER-beta) mRNAs in normal ovary, ovarian serous cystadenocarcinoma and ovarian cancer cell lines: down-regulation of ER-beta in neoplastic tissues. Journal of Clinical Endocrinology and Metabolism 83 1025-1028.

Burns KH, Agno JE, Chen L, Haupt B, Ogbonna SC, Korach KS \& Matzuk MM 2003 Sexually dimorphic roles of steroid hormone receptor signaling in gonadal tumorigenesis. Molecular Endocrinology 17 2039-2052.

Cheng J, Lee EJ, Madison LD \& Lazennec G 2004 Expression of estrogen receptor beta in prostate carcinoma cells inhibits invasion and proliferation and triggers apoptosis. FEBS Letters 566 169-172.

Couse JF, Curtis Hewitt S \& Korach KS 2000 Receptor null mice reveal contrasting roles for estrogen receptor alpha and beta in reproductive tissues. Journal of Steroid Biochemistry and Molecular Biology 74 287-296.

Greenlee RT, Murray T, Bolden S \& Wingo PA 2000 Cancer statistics. CA: A Cancer Journal for Clinicians 50 7-33.
Gustafsson JA 1999 Estrogen receptor beta-a new dimension in estrogen mechanism of action. Journal of Endocrinology 163 379-383.

Hatch KD, Beecham JB, Blessing JA \& Creasman WT 1991 Responsiveness of patients with advanced ovarian carcinoma to tamoxifen. A Gynecologic Oncology Group Study of second-line therapy in 105 patients. Cancer 68 269-271.

Havrilesky LJ, McMahon CP, Lobenhofer EK, Whitaker R, Marks JR \& Berchuck A 2001 Relationship between expression of coactivators and corepressors of hormone receptors and resistance of ovarian cancers to growth regulation by steroid hormones. Journal of the Society for Gynecologic Investigation 8 104-113.

Hayashido Y, Lucas A, Rougeot C, Godyna S, Argraves WS \& Rochefort H 1998 Estradiol and fibulin-1 inhibit motility of human ovarian- and breastcancer cells induced by fibronectin. International Journal of Cancer 75 654-658.

Helguero LA, Faulds MH, Gustafsson JA \& Haldosen LA 2005 Estrogen receptors alfa (ERalpha) and beta (ERbeta) differentially regulate proliferation and apoptosis of the normal murine mammary epithelial cell line HC11. Oncogene 24 6605-6616.

Herynk MH \& Fuqua SA 2004 Estrogen receptor mutations in human disease. Endocrine Reviews 25 869-898.

Jones J, Lagasse LD \& Karlan BY 1994 Steroid hormonal independence of HER-2/neu mRNA expression in four human ovarian carcinoma cell lines. Gynecologic Oncology 53 421-426.

Lacey JV Jr, Mink PJ, Lubin JH, Sherman ME, Troisi R, Hartge P, Schatzkin A \& Schairer C 2002 Menopausal hormone replacement therapy and risk of ovarian cancer. JAMA 288 334-341.

Lau KM, Mok SC \& Ho SM 1999 Expression of human estrogen receptoralpha and -beta, progesterone receptor, and androgen receptor mRNA in normal and malignant ovarian epithelial cells. PNAS 96 5722-5727.

Lazennec G, Bresson D, Lucas A, Chauveau C \& Vignon F 2001 ER beta inhibits proliferation and invasion of breast cancer cells. Endocrinology 142 4120-4130.

Lindberg MK, Moverare S, Skrtic S, Gao H, Dahlman-Wright K, Gustafsson JA \& Ohlsson C 2003 Estrogen receptor (ER)-beta reduces ERalpharegulated gene transcription,supporting a 'ying yang' relationship between ERalpha and ERbeta in mice. Molecular Endocrinology 17 203-208.

Livak KJ \& Schmittgen TD 2001 Analysis of relative gene expression data using real-time quantitative PCR and the $2^{-\Delta \Delta} C_{\mathrm{T}}$ method. Methods $\mathbf{2 5}$ 402-408.

Lu B, Leygue E, Dotzlaw H, Murphy LJ, Murphy LC \& Watson PH 1998 Estrogen receptor-beta mRNA variants in human and murine tissues. Molecular and Cellular Endocrinology 138 199-203.

Mak P, Leung YK, Tang WY, Harwood C \& Ho SM 2006 Apigenin suppresses cancer cell growth through ERbeta. Neoplasia 8 896-904.

Merchenthaler I \& Shugrue PJ 1999 Estrogen receptor-beta: a novel mediator of estrogen action in brain and reproductive tissues. Morphological considerations. Journal of Endocrinological Investigation 22 10-12.

Moll F, Katsaros D, Lazennec G, Hellio N, Roger P, Giacalone PL, Chalbos D, Maudelonde T, Rochefort H \& Pujol P 2002 Estrogen induction and overexpression of fibulin-1C mRNA in ovarian cancer cells. Oncogene 21 1097-1107.

Osborne CK \& Schiff R 2005 Estrogen-receptor biology: continuing progress and therapeutic implications. Journal of Clinical Oncology 23 1616-1622.

Pettersson K \& Gustafsson JA 2001 Role of estrogen receptor beta in estrogen action. Annual Review of Physiology 63 165-192.

Planas-Silva MD \& Weinberg RA 1997 Estrogen-dependent cyclin E-cdk2 activation through p21 redistribution. Molecular and Cellular Biology 17 4059-4069.

Poola I, Abraham J \& Liu A 2002a Estrogen receptor beta splice variant mRNAs are differentially altered during breast carcinogenesis. Journal of Steroid Biochemistry and Molecular Biology 82 169-179.

Poola I, Abraham J \& Baldwin K $2002 b$ Identification of ten exon deleted ERbeta mRNAs in human ovary, breast, uterus and bone tissues: alternate splicing pattern of estrogen receptor beta mRNA is distinct from that of estrogen receptor alpha. FEBS Letters 516 133-138. 
Price RH Jr, Lorenzon N \& Handa RJ 2000 Differential expression of estrogen receptor beta splice variants in rat brain: identification and characterization of a novel variant missing exon 4. Brain Research. Molecular Brain Research 80 260-268.

Price RH Jr, Butler CA, Webb P, Uht R, Kushner P \& Handa RJ 2001 A splice variant of estrogen receptor beta missing exon 3 displays altered subnuclear localization and capacity for transcriptional activation. Endocrinology 142 2039-2049.

Pujol P, Rey JM, Nirde P, Roger P, Gastaldi M, Laffargue F, Rochefort H \& Maudelonde T 1998 Differential expression of estrogen receptor-alpha and -beta messenger RNAs as a potential marker of ovarian carcinogenesis. Cancer Research $\mathbf{5 8}$ 5367-5373.

Rodriguez C, Patel AV, Calle EE, Jacob EJ \& Thun MJ 2001 Estrogen replacement therapy and ovarian cancer mortality in a large prospective study of US women. JAMA 285 1460-1465.

Rutherford T, Brown WD, Sapi E, Aschkenazi S, Munoz A \& Mor G 2000 Absence of estrogen receptor-beta expression in metastatic ovarian cancer. Obstetrics and Gynecology 96 417-421.

Scambia G, Benedetti-Panici P, Ferrandina G, Distefano M, Salerno G, Romanini ME, Fagotti A \& Mancuso S 1995 Epidermal growth factor, oestrogen and progesterone receptor expression in primary ovarian cancer: correlation with clinical outcome and response to chemotherapy. British Journal of Cancer 72 361-366.

Sierens JE, Scobie GA, Wilson J \& Saunders PT 2004 Cloning of oestrogen receptor beta from old and new world primates: identification of splice variants and functional analysis. Journal of Molecular Endocrinology 32 703-718.

Speirs V, Adams IP, Walton DS \& Atkin SL 2000 Identification of wild-type and exon 5 deletion variants of estrogen receptor beta in normal human mammary gland. Journal of Clinical Endocrinology and Metabolism 85 $1601-1605$.
Ståhlberg A, Åman P, Ridell B, Mostad P \& Kubista M 2003 A quantitative real-time PCR method for detection of B-Lymphocyte monoclonality by comparison of kappa and lambda immunoglobulin light chain expression. Clinical Chemistry 49 51-59.

Thomas TJ, Faaland CA, Adhikarakunnathu S, Watkins LF \& Thomas T 1998 Induction of p21 (CIP1/WAF1/SID1) by estradiol in a breast epithelial cell line transfected with the recombinant estrogen receptor gene: a possible mechanism for a negative regulatory role of estradiol. Breast Cancer Research and Treatment 47 181-193.

Treeck O, Pfeiler G, Federhofer B, Houlihan H, Vollmer A, Horn F \& Ortmann O 2007 Novel estrogen receptor beta transcript variants identified in human breast cancer cells affect cell growth and apoptosis of COS-1 cells. Molecular and Cellular Endocrinology 264 50-60.

Vendrell JA, Magnino F, Danis E, Duchesne MJ, Pinloche S, Pons M, Birnbaum D, Nguyen C, Theillet C \& Cohen PA 2004 Estrogen regulation in human breast cancer cells of new downstream gene targets involved in estrogen metabolism, cell proliferation and cell transformation. Journal of Molecular Endocrinology 32 397-414.

Vladusic EA, Hombsby AE, Guerra-Vladusic FK \& Lupa R 1998 Expression of estrogen receptor beta messenger RNA variant in breast cancer. Cancer Research 58 210-214.

Zhao C, Toresson G, Xu L, Koehler KF, Gustafsson JA \& Dahlman-Wright K 2005 Mouse estrogen receptor beta isoforms exhibit differences in ligand selectivity and coactivator recruitment. Biochemistry 44 7936-7944.

Received in final form 19 March 2007

Accepted 23 March 2007

Made available online as an Accepted Preprint 29 March 2007 